\title{
Hélène Piquet, La Chine au carrefour des traditions juridiques
}

\section{Leïla Choukroune}

\section{(2) OpenEdition}

1 Journals

Édition électronique

URL : http://journals.openedition.org/chinaperspectives/2453

DOI : 10.4000/chinaperspectives.2453

ISSN : 1996-4617

Éditeur

Centre d'étude français sur la Chine contemporaine

Édition imprimée

Date de publication : 15 septembre 2007

ISSN : 2070-3449

Référence électronique

Leilla Choukroune, "Hélène Piquet, La Chine au carrefour des traditions juridiques », China Perspectives [En ligne], 2007/3 | 2007, mis en ligne le 09 avril 2008, consulté le 24 septembre 2020. URL : http:// journals.openedition.org/chinaperspectives/2453; DOI : https://doi.org/10.4000/chinaperspectives. 2453

Ce document a été généré automatiquement le 24 septembre 2020.

(C) All rights reserved 


\title{
Hélène Piquet, La Chine au carrefour des traditions juridiques
}

\author{
Leïla Choukroune
}

$1 \quad$ Is law a transferable technology? This is in essence the question posed by the work of Hélène Piquet, Professor at the Faculty of Law and Political Science at the University of Quebec at Montreal. If the undertaking is not a new one-Shen Jiaben's China had already made attempts at legal integration-it has today developed to such dimensions and variety that the interpretation of transfers has become a very delicate task. What China has agreed to borrow from the cultures of civil law or common law thus places the country "at the crossroads of legal traditions". Following a generally descriptive opening section, in which the author nevertheless does useful work by placing the current policies in the historical perspective of the overhaul of Chinese law, the book finds its full meaning by offering a first-hand analysis of the Chinese doctrine of legal transplants . This is in fact the major and outstanding contribution that Hélène Piquet has made to the study of the reforms in progress. The edifice is thus constructed in two stages: a synthesis of the historical and contemporary debates, then the highlighting of the external influences on Chinese law through the concrete study of the codification of civil law and of the Contract Law of 1999. The first theoretical stage proposed by the work is most interesting. By synthesising the contributions made by great legal articles of the last 20 years, the author distinguishes between two schools of Chinese doctrine: one favourable to legal transplants that are considered to be a result of internationalisation, the other opposed to a cultural integration that is incapable of fulfilling China's needs. All this is founded on keen knowledge of the doctrine, which the author does not fail to put into perspective with the help of well-known references from Western jurists. The immense merit of this work is thus that it offers a genuine concentration of Chinese legal thought to a Western reader still largely unaware of the existence of the law in China. Situated "at the crossroads of legal traditions", China is also at the heart of a very competitive market in expertise as well as it is confronted, to use the neo-Marxist terminology favoured by proponents of a profound criticism of the law, with a new imperialism of normative exports . One is reminded of the idea of "Doing Business" used by the World Bank in irritating bad faith to stigmatise the model 
of civil law as unsuitable for the practice of business. The response of civil law specialists to this offensive of common law, though less scathing, consisted in a vast commercial operation in favour of a civil code, the bicentenary of which has recently been celebrated. These exchanges would remain relatively laughable if each side were not profoundly convinced of its own superiority. It is easier to understand, from this perspective, the criticisms relating to the fragmentation - which is in fact very real-of Chinese normative texts. Calls for standardisation are not always innocent and China's apparent instrumentalism is no doubt more complex than it appears . Hélène Piquet visibly seeks to shake off this quite widespread thesis of an instrumentalist China digging here and there for standards that are useful for its economic development. The idea of "forum shopping" is not strictly speaking Chinese, it is very much in fashion in the international arena, if it is looked at for example from the point of view of a company wishing to best protect its interests in fickle markets or in areas where the state is deprived of its regalian competence. The feature that distinguishes China would thus be how it sinicises what it has borrowed by adapting it to the local context through recourse to the theory of "Chinese characteristics" and of "bentuhua", something which, in the long term, would aim to construct a unique system. If it is totally novel, the Chinese legal "system", in so far as it is possible to comprehend it as a whole, still seems to lack a certain coherence. There was indeed a short-term instrumentalisation when, at the beginning of the 1980s, it was necessary to give a legal framework to foreign investment, and there is instrumentalisation again as the brand new property law proposes a synthesis between socialism and the market. To this objection of incoherence, practitioners could reply that the system functions in spite of everything and that this mix does not harm the security of business. This may be correct, but we remain fairly circumspect as to the long-term feasibility of the process, especially with regard to its application to other branches of the law. What about the relative formalism of Chinese criminal law and procedure applied to the defence of lawyers who are encouraged one day only to be regarded as dangerous disruptive elements the next? Is it not something of a risk to separate the granting of rights from the guarantee system initially planned to ensure their enforcement? In our view, the debate relating to the protection of individual rights should not be removed from the scope of this work, as the author sometimes leaves one to think it is . If the criticism concerning instrumentalism has no doubt had its day, this is because there is today something very different in the advertised desire for the "legalisation" (fazhihua) of Chinese society. In the space of thirty years, China has gone from a visceral rejection of the law and of legal professionals to a certain fascination for the power with which norms seem invested. We can thus agree with Hélène Piquet when it comes to underlining the complexity of the current legal landscape and the wealth of the doctrinal debates. What is now needed is to pay the greatest attention to the thoughts that animate a community of increasingly well-trained and often very well informed jurists. In the chapter dedicated to the renaissance of private law, Hélène Piquet shows with great clarity how the elaboration of the concept of civil society has strengthened the work of Chinese jurists in favour of the emergence of a law distinct from the state and thus more independent of politics. It is easily understood here that the technical nature of the law aims to encourage the emancipation from politics. Despite these comments pertaining to the present critical exercise, one must honour the outstanding work carried out by Hélène Piquet. By "translating” for legal experts the contemporary debates on doctrine, the author is already building, with a rare critical determination 
and a genuine educational sense, the "bridges between Chinese and Western jurists" that she pins her hopes on. 